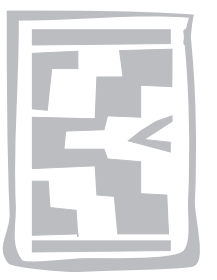

\title{
Elephant shrews as hosts of immature ixodid ticks
}

\author{
L.J. FOURIE ${ }^{1}$, I.G. HORAK ${ }^{2}$ and P.F. WOODALL ${ }^{3}$
}

\begin{abstract}
FOURIE, L.J., HORAK, I.G. \& WOODALL, P.F. 2005. Elephant shrews as hosts of immature ixodid ticks. Onderstepoort Journal of Veterinary Research, 72:293-301

Two hundred and seventy-three elephant shrews, consisting of 193 Elephantulus myurus, 67 Elephantulus edwardii and 13 animals belonging to other species, were examined for ixodid ticks at 18 localities in South Africa and Namibia. The immature stages of Ixodes rubicundus, Rhipicentor nuttalli, Rhipicephalus warburtoni and a Rhipicephalus pravus-like tick were the most numerous of the 18 tick species recovered. Substantial numbers of immature Rhipicephalus arnoldi, Rhipicephalus distinctus and Rhipicephalus exophthalmos were also collected from elephant shrews at particular localities.

Larvae of $I$. rubicundus were most numerous on E. myurus in Free State Province from April to July and nymphs from June to October. Larvae of $R$. nuttalli were most numerous on these animals during April, May, August and September, and nymphs in February and from April to August. The immature stages of $R$. warburtoni were collected from E. myurus only in Free State Province, and larvae were generally most numerous from December to August and nymphs from April to October.

Keywords: Elephant shrews, Ixodes rubicundus, ixodid ticks, macroscelids, Rhipicentor nuttalli, Rhipicephalus warburtoni
\end{abstract}

\section{INTRODUCTION}

The ixodid ticks that infest elephant shrews in southern Africa have been recorded by Theiler (1962), who listed 14 species, and reviewed by Fourie, Du Toit, Kok \& Horak (1995), who list 22 species. The ticks that infest these small mammals are of more

Department of Zoology and Entomology, University of the Free State, Bloemfontein, 9301 South Africa.

E-mail: fourie@clinvet.com

2 Department of Zoology and Entomology, University of the Free State, Bloemfontein, 9301 South Africa and Department of Veterinary Tropical Diseases, Faculty of Veterinary Science, University of Pretoria, Onderstepoort, 0110 South Africa

3 School of Veterinary Science, The University of Queensland, Brisbane, 4072 Australia

Accepted for publication 14 June 2005-Editor than purely academic interest in that rock elephant shrews, Elephantulus myurus, are the preferred hosts of the immature stages of three ticks capable of inducing paralysis in domestic animals (Fourie, Horak \& Van Den Heever 1992a; Fourie, Horak, Kok \& Van Zyl 2002). These ticks are Ixodes rubicundus, responsible for massive annual mortality amongst sheep (Spickett \& Heyne 1988), Rhipicentor nuttalli that can cause paralysis in dogs (Perchman 1976; Norval \& Colborne 1985), and Rhipicephalus warburtoni (then referred to as a tick belonging to the Rhipicephalus pravus group) that has been incriminated in paralysis in goat kids (Fourie, Horak \& Marais 1988a).

The hosts of the immature and adult stages of $I$. rubicundus have been recorded by Stampa (1959) and Horak, Moolman \& Fourie (1987a), and the role of $E$. myurus in the life cycle of this tick, colloquially 
known as the Karoo paralysis tick, has been highlighted by Du Toit, Fourie \& Horak (1994a, b) and Fourie \& Horak (1994). The hosts in Zimbabwe of adult $R$. nuttalli have been listed by Norval \& Colborne (1985), while in South Africa the hosts of both adult and immature ticks have been recorded by Fourie et al. (2002), who established the details of its life cycle. Walker, Keirans \& Horak (2000) have summarized the host records obtained by Fourie and his co-workers for $R$. warburtoni during extensive surveys they conducted in Free State Province between 1985 and 1991. Fourie et al. (1992a, 2002) have also documented the seasonal occurrence of the immature stages of the latter three ticks on $E$. myurus.

The economic importance of these ticks and the pivotal role of $E$. myurus in their life cycles prompted further surveys on these animals and on other species of elephant shrews, and the objective of this study was to determine both the species composition and seasonality of ticks that infest them.
Fleas were also collected during the surveys and have been recorded by Beaucournu, Horak \& Fourie (2003).

\section{MATERIALS AND METHODS}

Ticks were collected by one of two methods from elephant shrews. In the first $E$. myurus were trapped in box traps each month from August 1994 to June 1995 on the farm Spes Bona in central Free State Province. They were transported to the laboratory and individually caged above trays from which engorged larvae or nymphs that had detached were collected daily. Once all larvae and nymphs had detached, the elephant shrews were returned to their original habitats on the farm and released. The following month's trapping commenced a week after this release so that if the same shrews were recaptured they would have had adequate time to become re-infested with ticks. Despite intensive efforts no elephant shrews were trapped during July 1995.

TABLE 1 Elephant shrews and the localities at which they were examined for ixodid ticks

\begin{tabular}{|c|c|c|}
\hline \multicolumn{2}{|l|}{ Elephant shrew species } & \multirow{2}{*}{ Province or locality and coordinates } \\
\hline Common name & Scientific name (no. examined) & \\
\hline Short-snouted elephant shrew & Elephantulus brachyrynchus (4) & Pilanesberg NR $\left(25^{\circ} 15^{\prime} \mathrm{S}, 27^{\circ} 05^{\prime} \mathrm{E}\right)$ \\
\hline Cape elephant shrew & Elephantulus edwardii (67) & Gifberg $\left(31^{\circ} 47^{\prime} \mathrm{S}, 18^{\circ} 40^{\prime} \mathrm{E}\right)$ \\
\hline Bushveld elephant shrew & Elephantulus intufi (1) & $\begin{array}{l}\text { Clanwilliam }\left(32^{\circ} 11^{\prime} \mathrm{S}, 18^{\circ} 54^{\prime} \mathrm{E}\right) \\
\text { Erongo }\left(21^{\circ} 27^{\prime} \mathrm{S}, 15^{\circ} 52^{\prime} \mathrm{E}\right) \text { (Namibia) }\end{array}$ \\
\hline Rock elephant shrew & Elephantulus myurus (193) & $\begin{array}{l}\text { Free State Province } \\
\text { Môreson }\left(28^{\circ} 48^{\prime} \mathrm{S}, 27^{\circ} 13^{\prime} \mathrm{E}\right) \\
\text { Spes Bona }\left(29^{\circ} 07^{\prime} \mathrm{S}, 26^{\circ} 04^{\prime} \mathrm{E}\right) \\
\text { Wolvekop }\left(29^{\circ} 27^{\prime} \mathrm{S}, 26^{\circ} 40^{\prime} \mathrm{E}\right) \\
\text { Langberg }\left(29^{\circ} 36^{\prime} \mathrm{S}, 25^{\circ} 28^{\prime} \mathrm{E}\right) \\
\text { Preezfontein }\left(29^{\circ} 50^{\prime} \mathrm{S}, 25^{\circ} 23^{\prime} \mathrm{E}\right) \\
\text { Welbedacht Dam }\left(29^{\circ} 51^{\prime} \mathrm{S}, 26^{\circ} 53^{\prime} \mathrm{E}\right) \\
\text { Tussen-die-Riviere NR }\left(30^{\circ} 29^{\prime} \mathrm{S}, 26^{\circ} 15^{\prime} \mathrm{E}\right) \\
\text { Northern provinces } \\
\text { Mapungubwe }\left(22^{\circ} 12^{\prime} \mathrm{S}, 29^{\circ} 21^{\prime} \mathrm{E}\right) \\
\text { Pafuri }\left(23^{\circ} 27^{\prime} \mathrm{S}, 31^{\circ} 19^{\prime} \mathrm{E}\right)(\mathrm{KNP}) \\
\text { Gustav Kliengbiel NR }\left(25^{\circ} 06^{\prime} \mathrm{S}, 30^{\circ} 31^{\prime} \mathrm{E}\right) \\
\text { Pilanesberg NR }\left(25^{\circ} 15^{\prime} \mathrm{S}, 27^{\circ} 05^{\prime} \mathrm{E}\right) \\
\text { Pretoria district }\left(25^{\circ} 45^{\prime} \mathrm{S}, 28^{\circ} 12^{\prime} \mathrm{E}\right)\end{array}$ \\
\hline Smith's rock elephant shrew & Elephantulus rupestris (6) & $\begin{array}{l}\text { Avis }\left(22^{\circ} 35^{\prime} \mathrm{S}, 17^{\circ} 07^{\prime} \mathrm{E}\right) \text { (Namibia) } \\
\text { Beaufort West }\left(32^{\circ} 21^{\prime} \mathrm{S}, 22^{\circ} 35^{\prime} \mathrm{E}\right)\end{array}$ \\
\hline Short-eared elephant shrew & Macroscelides proboscideus (1) & Victoria West $\left(31^{\circ} 24^{\prime} \mathrm{S}, 23^{\circ} 07^{\prime} \mathrm{E}\right)$ \\
\hline Four-toed elephant shrew & Petrodromus tetradactylus (1) & Pafuri $\left(23^{\circ} 27^{\prime} \mathrm{S}, 31^{\circ} 19^{\prime} \mathrm{E}\right)(\mathrm{KNP})$ \\
\hline
\end{tabular}


The detached, engorged larvae and nymphs were washed in water to remove traces of urine and prevent the growth of fungi and were maintained at $20^{\circ} \mathrm{C}$ and a relative humidity of approximately $90 \%$ in permanent darkness. Once moulting was completed the various species were identified from the newly emerged nymphs or adults and counted. In the second method elephant shrews were captured in box traps, euthanased and their carcasses processed for the recovery of ticks as described by Fourie et al. (1992a).

The seasonal occurrence of the immature stages of I. rubicundus, $R$. nuttalli and $R$. warburtoni was determined from the average monthly tick burdens of $E$. myurus examined within Free State Province, the only province in which ticks were collected from elephant shrews during every month of the year.

\section{RESULTS AND DISCUSSION}

The species of elephant shrews examined, and the localities at which they were trapped are summarized in Table 1.

Tick collections were made at 18 localities from 273 elephant shrews belonging to seven species.

The ticks collected from the elephant shrews are summarized in Tables 2-8.

TABLE 2 Ixodid ticks collected from 66 Elephantulus edwardii on the farm Gifberg $\left(31^{\circ} 47^{\prime} \mathrm{S}, 18^{\circ} 40^{\prime} \mathrm{E}\right)$ in the Western Cape Province

\begin{tabular}{|l|r|r|r|r|}
\hline \multirow{2}{*}{ Tick species } & \multicolumn{2}{|l|}{ Total number of ticks collected } & \multirow{2}{*}{$\begin{array}{l}\text { Number of } \\
\text { infested animals }\end{array}$} \\
\cline { 2 - 5 } & Larvae & Nymphs & Total & \\
\hline Haemaphysalis hyracophila & 1 & 2 & 3 & 1 \\
Haemaphysalis leachi & 1 & 0 & 2641 & 1 \\
Ixodes rubicundus & 1962 & 679 & 16 & 11 \\
Rhipicephalus arnoldi & 0 & 1 & 54 & 3 \\
Rhipicephalus distinctus & 15 & 1 & 10 & 5 \\
Rhipicephalus exophthalmos & 53 & 4 & 21 & 9 \\
Rhipicephalus gertrudae & 6 & 1 & & \\
Rhipicephalus sp. & 20 & 1 & & \\
\hline
\end{tabular}

TABLE 3 Ixodid ticks collected from 54 Elephantulus myurus on the farm Langberg (29³6'S, $\left.25^{\circ} 28^{\prime} E\right)$ in Free State Province

\begin{tabular}{|l|c|c|c|c|}
\hline \multirow{2}{*}{ Tick species } & \multicolumn{2}{|l|}{ Total number of ticks collected } & \multirow{2}{*}{$\begin{array}{l}\text { Number of } \\
\text { infested animals }\end{array}$} \\
\cline { 2 - 5 } & Larvae & Nymphs & Total & 4 \\
\hline Amblyomma marmoreum & 5 & 1 & 6 & 1 \\
Haemaphysalis hyracophila & 0 & 1 & 1 & 1 \\
Hyalomma truncatum & 1 & 0 & 1521 & 2 \\
Ixodes rubicundus & 1168 & 353 & 2 & 2 \\
Rhipicephalus evertsi evertsi & 1 & 1 & 534 & 54 \\
Rhipicephalus warburtoni & 1862 & 672 & & \\
\hline
\end{tabular}

TABLE 4 Ixodid ticks collected from $86^{*}$ Elephantulus myurus on the farms Spes Bona $\left(29^{\circ} 07^{\prime} \mathrm{S}, 26^{\circ} 04^{\prime} \mathrm{E}\right)$ and Wolvekop (29²7'S, $\left.26^{\circ} 40^{\prime} \mathrm{E}\right)$ in Free State Province

\begin{tabular}{|l|c|c|c|c|}
\hline \multirow{2}{*}{ Tick species } & \multicolumn{2}{|l|}{ Total number of ticks collected } & \multirow{2}{*}{$\begin{array}{l}\text { Number of } \\
\text { infested animals }\end{array}$} \\
\cline { 2 - 4 } & Larvae & Nymphs & Total & \\
\hline Haemaphysalis hyracophila & 1 & 0 & 1 & 1 \\
Ixodes rubicundus** & 146 & 538 & 684 & 37 \\
Rhipicentor nuttalli & 361 & 75 & 436 & 54 \\
Rhipicephalus arnoldi & 151 & 50 & 201 & 45 \\
Rhipicephalus distinctus & 4 & 1 & 5 & 4 \\
Rhipicephalus warburtoni & 2162 & 609 & 2771 & 70 \\
\hline
\end{tabular}

* $\quad=$ Although ticks were collected from 86 animals, only those from 72 animals were identified

** = Engorged larvae and nymphs of $I$. rubicundus that detached from 21 heavily infested animals were used for experimental purposes without their numbers being recorded 
Elephant shrews as hosts of ixodid ticks

TABLE 5 Ixodid ticks collected from 24 Elephantulus myurus on the farm Môreson (2848’S, $\left.27^{\circ} 13^{\prime} E\right)$ in Free State Province

\begin{tabular}{|l|c|c|c|c|}
\hline \multirow{2}{*}{ Tick species } & \multicolumn{2}{|l|}{ Total number of ticks collected } & \multirow{2}{*}{$\begin{array}{l}\text { Number of } \\
\text { infested animals }\end{array}$} \\
\cline { 2 - 4 } & Larvae & Nymphs & Total & 1 \\
\hline Hyalomma marginatum rufipes & 1 & 0 & 1 & 14 \\
Ixodes rubicundus & 13 & 87 & 100 & 22 \\
Rhipicentor nuttalli & 147 & 70 & 217 & 2 \\
Rhipicephalus distinctus & 2 & 0 & 240 & 20 \\
Rhipicephalus warburtoni & 171 & 69 & & \\
\hline
\end{tabular}

TABLE 6 Ixodid ticks collected from 8 Elephantulus myurus at various localities in Free State Province

\begin{tabular}{|c|c|c|c|c|c|}
\hline \multirow{2}{*}{ Tick species } & \multicolumn{3}{|c|}{ Number of ticks collected } & \multirow{2}{*}{$\begin{array}{l}\text { Infested } \\
\text { animals }\end{array}$} & \multirow{2}{*}{$\begin{array}{l}\text { Coordinates of } \\
\text { collection localities }\end{array}$} \\
\hline & Larvae & Nymphs & Total & & \\
\hline Hyalomma truncatum & 0 & 8 & 8 & 1 & $\left(30^{\circ} 29^{\prime} \mathrm{S}, 26^{\circ} 15^{\prime} \mathrm{E}\right)$ \\
\hline Ixodes rubicundus & 155 & 117 & 272 & 6 & $\begin{array}{l}\left(29^{\circ} 50^{\prime} \mathrm{S}, 25^{\circ} 23^{\prime} \mathrm{E}\right) \\
\left(29^{\circ} 51^{\prime} \mathrm{S}, 26^{\circ} 53^{\prime} \mathrm{E}\right) \\
\left(30^{\circ} 29^{\prime} \mathrm{S}, 26^{\circ} 15^{\prime} \mathrm{E}\right)\end{array}$ \\
\hline Rhipicephalus evertsi evertsi & 1 & 0 & 1 & 1 & $\left(29^{\circ} 51^{\prime} \mathrm{S}, 26^{\circ} 53^{\prime} \mathrm{E}\right)$ \\
\hline Rhipicephalus warburtoni & 421 & 47 & 468 & 7 & $\begin{array}{l}\left(29^{\circ} 50^{\prime} \mathrm{S}, 25^{\circ} 23^{\prime} \mathrm{E}\right) \\
\left(29^{\circ} 51^{\prime} \mathrm{S}, 26^{\circ} 53^{\prime} \mathrm{E}\right) \\
\left(30^{\circ} 29^{\prime} \mathrm{S}, 26^{\circ} 15^{\prime} \mathrm{E}\right)\end{array}$ \\
\hline
\end{tabular}

TABLE 7 Ixodid ticks collected from 21 Elephantulus myurus in the four northern provinces of South Africa

\begin{tabular}{|c|c|c|c|c|c|}
\hline \multirow{2}{*}{ Tick species } & \multicolumn{3}{|c|}{ Number of ticks collected } & \multirow{2}{*}{$\begin{array}{l}\text { Infested } \\
\text { animals }\end{array}$} & \multirow{2}{*}{$\begin{array}{l}\text { Coordinates of } \\
\text { collection localities }\end{array}$} \\
\hline & Larvae & Nymphs & Total & & \\
\hline Ixodes bakeri & 0 & 0 & 1 female & 1 & $\left(25^{\circ} 06^{\prime} \mathrm{S}, 30^{\circ} 31^{\prime} \mathrm{E}\right)$ \\
\hline Rhipicentor nuttalli & 176 & 117 & 293 & 13 & $\begin{array}{l}\left(23^{\circ} 27^{\prime} \mathrm{S}, 31^{\circ} 19^{\prime} \mathrm{E}\right) \\
\left(25^{\circ} 45^{\prime} \mathrm{S}, 28^{\circ} 12^{\prime} \mathrm{E}\right)\end{array}$ \\
\hline Rhipicephalus pravus group & 679 & 158 & 837 & 13 & $\begin{array}{l}\left(23^{\circ} 27^{\prime} \mathrm{S}, 31^{\circ} 19^{\prime} \mathrm{E}\right) \\
\left(25^{\circ} 15^{\prime} \mathrm{S}, 27^{\circ} 05^{\prime} \mathrm{E}\right) \\
\left(25^{\circ} 45^{\prime} \mathrm{S}, 28^{\circ} 12^{\prime} \mathrm{E}\right)\end{array}$ \\
\hline
\end{tabular}

Eighteen tick species were recovered and the immature stages of $I$. rubicundus, $R$. nuttalli, $R$. warburtoni and a Rhipicephalus pravus-like tick were the most numerous of these. However, substantial numbers of immature Rhipicephalus arnoldi, Rhipicephalus distinctus and Rhipicephalus exopthalmos were also collected from elephant shrews at particular localities.

\section{Ixodes rubicundus}

Large numbers of larvae and nymphs of I. rubicundus were collected from E. myurus in Free State Province and from Elephantulus edwardii in Western Cape Province in the present study. Stampa (1959) collected approximately 200 larvae and nymphs from nine Elephantulus spp. in the New Bethesda region of the Eastern Cape Province, and more than 2600 from 76 Smith's red rock rabbits, Pronolagus rupestris, at the same locality. On the other hand, Horak \& Fourie (1991) recovered only six larvae from 28 red rock rabbits they examined on two farms in south-western Free State Province, whereas 132 rock elephant shrews examined on the same farms harboured 4331 larvae and nymphs (Fourie et al. 1992a). It would thus appear that these small mammals supplant each other as hosts for the immature stages of $I$. rubicundus depending upon locality and environment.

Larvae were most numerous on rock elephant shrews in Free State Province from April to July and 
L.J. FOURIE, I.G. HORAK \& P.F. WOODALL

TABLE 8 Ixodid ticks collected from various species of elephant shrews at several localities

\begin{tabular}{|c|c|c|}
\hline $\begin{array}{l}\text { Elephant shrew species } \\
\text { (no. examined) }\end{array}$ & Locality & $\begin{array}{l}\text { Tick species } \\
\text { (no. of infested animals) }\end{array}$ \\
\hline Elephantulus brachyrynchus (4) & $\begin{array}{l}\text { Pilanesberg, } \\
\text { North West Province }\end{array}$ & $\begin{array}{l}\text { Hyalomma truncatum } 1 \text { larva (1) } \\
\text { Ixodes sp. } 1 \text { nymph (1) } \\
\text { Rhipicephalus pravus group } 48 \text { nymphs (4) }\end{array}$ \\
\hline Elephantulus edwardii (1) & $\begin{array}{l}\text { Clanwilliam, } \\
\text { Western Cape Province }\end{array}$ & $\begin{array}{l}\text { Ixodes rubicundus } 2 \text { nymphs (1) } \\
\text { Rhipicentor nuttalli } 7 \text { nymphs (1) }\end{array}$ \\
\hline Elephantulus intufi (1) & Erongo, Namibia & Rhipicentor nuttalli 3 nymphs (1) \\
\hline Elephantulus rupestris (1) & $\begin{array}{l}\text { Beaufort West, } \\
\text { Western Cape Province }\end{array}$ & Rhipicephalus sp. 8 larvae, 11 nymphs (1) \\
\hline Elephantulus rupestris (5) & $\begin{array}{l}\text { Avis, } \\
\text { Namibia }\end{array}$ & $\begin{array}{l}\text { Rhipicephalus exophthalmos } 1 \text { larva, } 35 \text { nymphs (5) } \\
\text { Rhipicephalus sp. } 1 \text { nymph (1) }\end{array}$ \\
\hline Macroscelides proboscideus (1) & $\begin{array}{l}\text { Victoria West, } \\
\text { Northern Cape Province }\end{array}$ & Rhipicephalus exophthalmos 51 larvae, 15 nymphs (1) \\
\hline Petrodromus tetradactylus (1) & $\begin{array}{l}\text { Pafuri, } \\
\text { Limpopo Province }\end{array}$ & $\begin{array}{l}\text { Haemaphysalis leachi } 2 \text { nymphs (1) } \\
\text { Rhipicephalus kochi } 1 \text { larva, } 74 \text { nymphs (1) }\end{array}$ \\
\hline
\end{tabular}

nymphs from June to October (Fig. 1A), matching the seasonal occurrence recorded by Fourie et al. (1992a) on these animals in south-western Free State Province during 1985. The 4-month difference in peak activity between larvae and nymphs (April to August) agrees with the observations of Stampa (1959) and Fourie et al. (1992a) and represents the moulting period of detached larvae and their subsequent attachment to hosts as newly moulted nymphs.

The vast majority of larvae that infest elephant shrews during autumn and early winter originate from eggs deposited by females during the winter of the previous year. These eggs over-summer in a state of diapause and larvae only hatch in autumn (Fourie \& Horak 1994). Engorged nymphs that detach from elephant shrews in late winter and spring also over-summer in a state of diapause and only moult to adults during late summer and autumn of the following year (Fourie \& Horak 1994). The life cycle thus takes 2 years to complete, with the immature stages present during the cooler months of the first year and the adults during the same months of the second year.

Stampa (1959) collected adult $I$. rubicundus from several wild carnivores in the New Bethesda region, and Horak et al. (1987a) have suggested that caracals, Caracal caracal, are one of the preferred hosts of this tick. Subsequent collections from wild carnivores as well as from domestic dogs indicate that several species are suitable hosts for adult $I$. rubicundus (Horak, Braack, Fourie \& Walker 2000; Jacobs, Fourie, Kok \& Horak 2001; Horak \& Matthee 2003). Wild bovids that frequent mountain slopes, namely mountain reedbuck, Redunca fulvorufula, grey rhebok, Pelea capreolus, and eland, Taurotragus oryx, as well as domestic sheep on mountainous pastures, also serve as hosts for adult ticks (Stampa 1959; Fourie et al. 1988b; Horak, Fourie, Novellie \& Williams 1991). Paralysis in sheep and goats is positively correlated with the intensity of infestation of female I. rubicundus and is observed during the cooler months of the year (Fourie, Petney, Horak \& De Jager 1989; Fourie, Horak \& Van Zyl 1992b).

\section{Rhipicentor nuttalli}

The genus Rhipicentor contains only two species, Rhipicentor bicornis and Rhipicentor nuttalli, whose distributions are restricted to Africa (Theiler 1961, 1962). $R$. nuttalli has been recorded in the Eastern and Western Cape, Free State, Gauteng, NorthWest and Limpopo provinces, South Africa (Theiler 1961; Du Toit 1993). In Namibia it occurs north of Windhoek, and it is also present in Botswana and Zimbabwe (Theiler 1961; Norval \& Colborne 1985). In this study its immature stages were collected from E. myurus in central Free State Province, northern Gauteng Province and in northern and northeastern Limpopo Province, and from E. edwardii in south-western Western Cape Province and Elephan- 

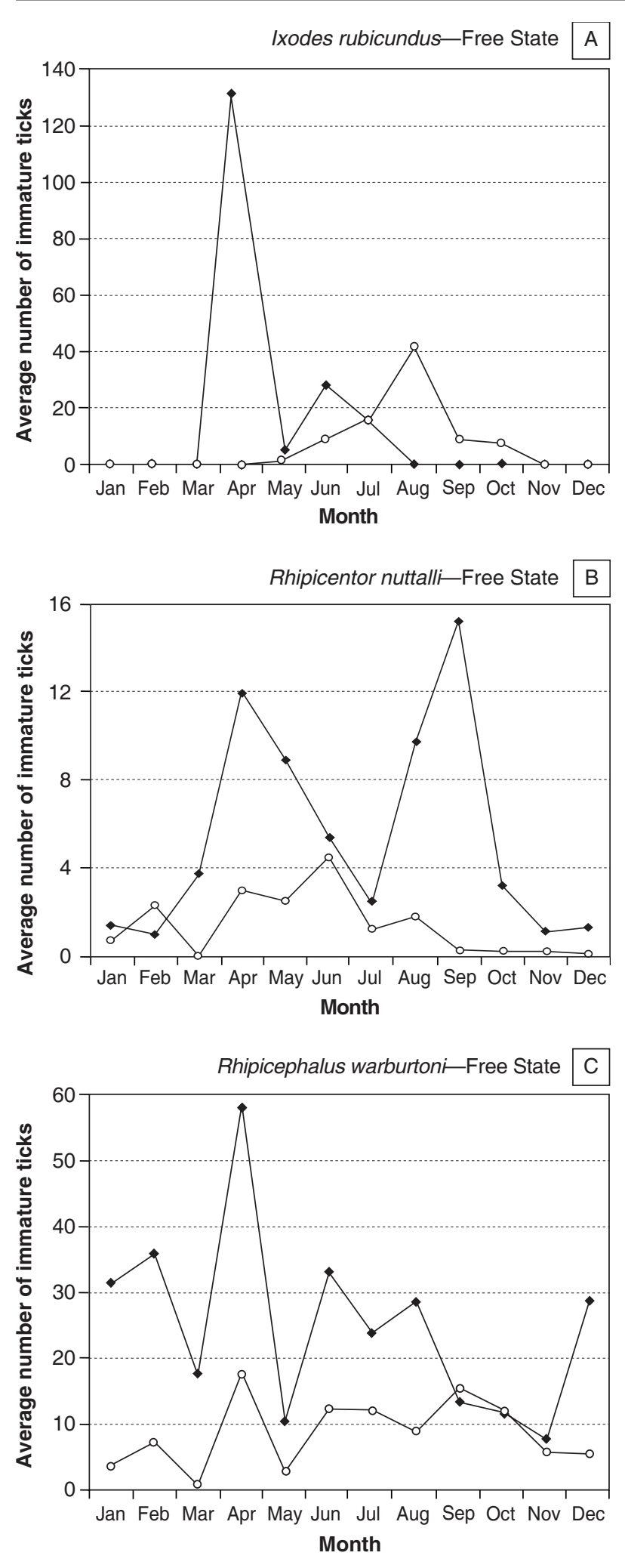

$$
\leftrightarrow \text { Larvae } \quad \text { - Nymphs }
$$

FIG. 1 The seasonal occurrence of the immature stages of (A) Ixodes rubicundus, (B) Rhipicentor nuttalli, and (C) Rhipicephalus warburtoni on rock elephant shrews in Free State Province, South Africa tulus intufi at Erongo, Namibia. R. bicornis occurs in the northern regions of South Africa and in Zimbabwe, northern Namibia and Zambia, and is widely distributed in Central Africa (Theiler 1961; Walker 1991).

The hosts of the immature stages of $R$. nuttalli were unknown until Du Toit (1993) collected larvae and nymphs from E. myurus in Free State Province. Adult $R$. nuttalli has been collected from domestic dogs and several wild carnivore species as well as from the South African hedgehog, Atelerix frontalis and porcupine, Hystrix africaeaustralis (Theiler 1961; Walker 1991; Horak et al. 2000). Norval \& Colborne (1985) state that whereas $R$. nuttalli is known in South Africa as the hedgehog tick, their findings in Zimbabwe indicate that the adults are principally parasites of leopards, Panthera pardus, and that its distribution is restricted to the rocky habitats normally favoured by these animals.

The large number of $E$. myurus infested with $R$. nuttalli in the present study confirms the observation by Du Toit (1993) that they are hosts of the immature stages of this tick. The collection of nymphs from $E$. edwardii and E. intufi suggests that these animals, and possibly other species of elephant shrews, are also suitable hosts for the immature stages of this tick, particularly in those regions in which $E$. myurus does not occur.

Although immature ticks were present on E. myurus throughout the year, the majority of larvae were collected in April and May and during August and September and nymphs in February and from April to August (Fig. 1B). This differs somewhat from the findings of Fourie et al. (2002), also in Free State Province, that larvae were generally most numerous during the period March to September, and nymphs during May to October. Theiler (1962) noted that adult ticks are common on dogs in the Clanwilliam district in the Western Cape Province and in the Omaruru district, Namibia during late summer. In Gauteng and Free State Provinces adult ticks have been collected from wild carnivores in September, October and December (Horak et al. 2000). In Zimbabwe, however, Norval \& Colborne (1985) found that adult ticks were present throughout the year.

\section{Rhipicephalus arnoldi}

This tick utilizes Smith's red rock rabbits as hosts for all its developmental stages (Horak et al. 1991; Horak \& Fourie 1991), but large numbers of immature ticks have also been collected from rock das- 
sies, Procavia capensis (Horak \& Fourie 1986; Horak et al. 1991). It has been suggested by Horak \& Fourie (1986) that, even if those on rock dassies are taken into account, the low ratio of immature to adult ticks implies that some other animal could also harbour considerable numbers of immature ticks of this species. It would now appear as if rock elephant shrews might fulfil this role in Free State Province. As their common names imply rock dassies, red rock rabbits and rock elephant shrews inhabit the same rocky habitats (Skinner \& Smithers 1990), and since they all have dense pelts it is not surprising that they host some tick species in common. However, whereas rock dassies are also hosts of adult Haemaphysalis hyracophila and adult $R$. distinctus, and red rock rabbits of adult $R$. arnoldi (Horak \& Fourie 1986, 1991; Horak et al. 1991), rock elephant shrews harbour only the immature stages of these species.

\section{Rhipicephalus distinctus}

This is a tick of rock dassies (Horak \& Fourie 1986; Walker et al. 2000), and sympatry between these animals and elephant shrews probably contributed to its presence on $11 \mathrm{E}$. edwardii in the Western Cape Province (Table 2) and on six E. myurus in Free State Province (Tables 4 and 5).

\section{Rhipicephalus exophthalmos}

Two E. edwardii examined in the Western Cape Province were infested with larvae and one with a nymph of $R$. exophthalmos (Table 2). The immature stages of this tick were also present on Elephantulus rupestris at Avis, Namibia, and on the single Macroscelides proboscideus examined at Victoria West, Northern Cape Province (Table 8). Scrub hares, Lepus saxatilis, which incidentally are also hosts of adult $R$. exophthalmos, are the only other animals recorded as hosts for the immature stages of this tick (Walker et al. 2000). Theiler (1962) lists nearly all elephant shrew species as hosts of the immature stages of a closely related species, namely Rhipicephalus oculatus. It is, however, possible that several of her records refer to R. exophthalmos, which has only recently been described (Keirans, Walker, Horak \& Heyne 1993).

\section{Rhipicephalus gertrudae}

The adults of $R$. gertrudae feed on domestic and wild ruminants and carnivores and its immature stages on murid rodents (Walker et al. 2000; Horak \& Matthee 2003) and the presence of its immature stages on E. edwardii in the Western Cape Prov- ince is possibly accidental (Table 2). This tick occurs in the southern, central and western regions of South Africa and in Namibia (Walker et al. 2000).

\section{Rhipicephalus kochi}

Although widespread elsewhere in East Africa, $R$. kochi has been collected only in the far north-east of Limpopo and KwaZulu-Natal Provinces in South Africa. The preferred hosts of all stages of development are medium-sized and larger antelopes and scrub hares (Walker et al. 2000). Judging by the single larva and large number of nymphs collected from the single four-toed elephant shrew examined at Pafuri in north-eastern Limpopo Province (Table 8), these animals appear to be good hosts of the immature stages of $R$. kochi.

\section{Rhipicephalus pravus group}

The immature stages of this $R$. pravus-like tick were present on E. myurus in northern Gauteng Province and north-eastern Limpopo Province, and its nymphs on E. myurus and Elephantulus brachyrynchus in North-West Province (Tables 7 and 8). All its parasitic stages have been collected from scrub hares at Shingwedzi and Pafuri in the Kruger National Park in north-eastern Limpopo Province, and on farms in the north-west of this province (Horak, Spickett, Braack \& Penzhorn 1993; Horak, Spickett, Braack, Penzhorn, Bagnall \& Uys 1995). Walker et al. (2000) place R. arnoldi, R. exophthalmos, R. kochi, R. oculatus, $R$. pravus and $R$. warburtoni in the $R$. pravus group of ticks on the morphological characters of their immature stages and suggest that these stages favour macroscelids as hosts. The validity of their grouping is supported by the present study in which, with the exception of those of $R$. oculatus, the immature stages of all these ticks were collected from elephant shrews.

\section{Rhipicephalus warburtoni}

This tick has only recently been described (Walker et al. 2000). It was previously variously referred to as an atypical strain of Rhipicephalus appendiculatus (Theiler 1949); as Rhipicephalus pravus (Theiler 1962); as an R. pravus-like tick (Fourie et al. 1988a, b); as an Rhipicephalus punctatus-like tick (Fourie \& Horak 1990); and as Rhipicephalus punctatus in several publications by Fourie \& Horak and their coworkers. The preferred hosts of the adults are domestic and wild ruminants and hares, and elephant shrews and hares are the preferred hosts of the immature stages (Fourie et al. 1992a; Walker et al. 2000). Its distribution is virtually confined to the 
central and southern regions of Free State Province (Walker et al. 2000), and its presence on 171 of the 182 E. myurus examined in this province is thus not unexpected (Tables 3-6).

Larvae were generally most numerous from December to August and nymphs from April to October (Fig. 1C). With the exception of April, when larval numbers were exceptionally high, this pattern of seasonality is fairly similar to that recorded by Fourie et al. (1992a). Most adults of this species are present on Angora goats in south-western Free State Province from September or November to February (Fourie \& Horak 1991), and it was during this period that paralysis was observed in goat kids (Fourie et al. 1988a).

\section{Other species}

The immature stages of the remaining tick species should all be considered as "stragglers". Adult Amblyomma marmoreum infests tortoises and its immature stages are found on these animals as well as ground-frequenting birds, hares, carnivores and ruminants (Norval 1975; Horak, Maclvor, Petney \& De Vos 1987b). Adult and immature H. hyracophila are parasites of rock dassies (Horak \& Fourie 1986), whereas adults of Haemaphysalis leachi are parasites of carnivores and its immature stages of murid rodents (Norval 1984; Fourie et al. 1992a). However, the latter may also occur on the same hosts as the adults (Horak \& Matthee 2003). Adult Hyalomma marginatum rufipes and Hyalomma truncatum infest large herbivorous animals and their immature stages infest hares (Norval 1982; Horak \& Fourie 1991). All stages of development of Ixodes bakeri infest shrews and rodents, with a particular preference for Otomys spp. (Walker 1991), while adult Rhipicephalus evertsi evertsi feeds on equids and ruminants and its immature stages on these animals and on hares (Walker et al. 2000).

\section{ACKNOWLEDGEMENTS}

We are most grateful to the farmers, landowners and nature reserve managers for permission to collect elephant shrews on the properties under their ownership or jurisdiction. We are particularly indebted to Mr E.J. Williams who was responsible for the collection of ticks from many of the animals.

\section{REFERENCES}

BEAUCOURNU, J.-C., HORAK, I.G. \& FOURIE, L.J. 2003. Fleas of elephant shrews (Mammalia, Macroscelidea), and a new host and locality record for Macroscelidopsylla albertyni De Meillon \& Marcus, 1958 (Siphonaptera, Chimaeropsyllidae). Onderstepoort Journal of Veterinary Research, 70:251-253.

DU TOIT, J.S. 1993. Ecophysiology and host status of the rock elephant shrew, Elephantulus myurus (Thomas \& Schwann, 1906). M.Sc. dissertation: University of the Free State, Bloemfontein.

DU TOIT, J.S., FOURIE, L.J. \& HORAK, I.G. 1994a. Sequential feeding of Ixodes rubicundus on its natural host, Elephantulus myurus: effects on tick mass and on engorgement and moulting success. Onderstepoort Journal of Veterinary Research, 61:143-147.

DU TOIT, J.S., FOURIE, L.J. \& HORAK, I.G. 1994b. Detachment rhythms of immature Ixodes rubicundus from their natural host, the rock elephant shrew (Elephantulus myurus). Onderstepoort Journal of Veterinary Research, 61:149-153.

FOURIE, L.J., HORAK, I.G. \& MARAIS, L. 1988a. An undescribed Rhipicephalus species associated with field paralysis of Angora goats. Journal of the South African Veterinary Association, 59:47-49.

FOURIE, L.J., HORAK, I.G. \& MARAIS, L. 1988b. The seasonal abundance of adult ixodid ticks on Merino sheep in the southwestern Orange Free State. Journal of the South African Veterinary Association, 59:191-194.

FOURIE, L.J., PETNEY, T.N., HORAK, I.G. \& DE JAGER, C. 1989. Seasonal incidence of Karoo paralysis in relation to the infestation density of female Ixodes rubicundus. Veterinary Parasitology, 33:319-328.

FOURIE, L.J. \& HORAK, I.G. 1990. Parasites of cattle in the south western Orange Free State. Journal of the South African Veterinary Association, 61:27-28.

FOURIE, L.J. \& HORAK, I.G. 1991. The seasonal activity of adult ixodid ticks on Angora goats in the south western Orange Free State. Journal of the South African Veterinary Association, 62:104-106.

FOURIE, L.J., HORAK, I.G. \& VAN DEN HEEVER, J.J. 1992a. The relative host status of rock elephant shrews Elephantulus myurus and Namaqua rock mice Aethomys namaquensis for economically important ticks. South African Journal of Zoology, 27:108-114.

FOURIE, L.J., HORAK, I.G. \& VAN ZYL, J.M. 1992b. Seasonal occurrence of Karoo paralysis in Angora goats in relation to the infestation density of female Ixodes rubicundus. Veterinary Parasitology, 41:249-254.

FOURIE, L.J. \& HORAK, I.G. 1994. The life cycle of Ixodes rubicundus (Acari: Ixodidae) and its adaptation to a hot, dry environment. Experimental and Applied Acarology, 18:23-35.

FOURIE, L.J., DU TOIT, J.S., KOK, D.J. \& HORAK, I.G. 1995. Arthropod parasites of elephant-shrews, with particular reference to ticks. Mammal Review, 25:31-37.

FOURIE, L.J., HORAK, I.G., KOK, D.J. \& VAN ZYL, W. 2002. Hosts, seasonal occurrence and life cycle of Rhipicentor nuttalli (Acari: Ixodidae). Onderstepoort Journal of Veterinary Research, 69:177-187.

HORAK, I.G. \& FOURIE, L.J. 1986. Parasites of domestic and wild animals in South Africa. XIX. Ixodid ticks and fleas on rock dassies (Procavia capensis) in the Mountain Zebra National Park. Onderstepoort Journal of Veterinary Research, 53:123-126.

HORAK, I.G., MOOLMAN, L.C. \& FOURIE, L.J. 1987a. Some wild hosts of the Karoo paralysis tick, Ixodes rubicundus Neumann, 1904 (Acari: Ixodidae). Onderstepoort Journal of Veterinary Research, 54:49-51.

HORAK, I.G., MACIVOR, K.M. DE F., PETNEY, T.N. \& DE VOS, V. 1987b. Some avian and mammalian hosts of Amblyomma 
hebraeum and Amblyomma marmoreum (Acari: Ixodidae). Onderstepoort Journal of Veterinary Research, 54:397-403.

HORAK, I.G., FOURIE, L.J., NOVELLIE, P.A. \& WILLIAMS, E.J. 1991. Parasites of domestic and wild animals in South Africa. XXVI. The mosaic of ixodid tick infestations on birds and mammals in the Mountain Zebra National Park. Onderstepoort Journal of Veterinary Research, 58, 125-136.

HORAK, I.G. \& FOURIE, L.J. 1991. Parasites of domestic and wild animals in South Africa. XXIX. Ixodid ticks on hares in the Cape Province and on hares and red rock rabbits in the Orange Free State. Onderstepoort Journal of Veterinary Research, 58:261-270.

HORAK, I.G., SPICKETT, A.M., BRAACK, L.EO. \& PENZHORN, B.L. 1993. Parasites of domestic and wild animals in South Africa. XXXII. Ixodid ticks on scrub hares in the Transvaal. Onderstepoort Journal of Veterinary Research, 60: 163-174.

HORAK, I.G., SPICKETT, A.M., BRAACK, L.E.O., PENZHORN, B.L., BAGNALL, R.J. \& UYS, A.C. 1995. Parasites of domestic and wild animals in South Africa. XXXIII. Ixodid ticks on scrub hares in the north-eastern regions of Northern and Eastern Transvaal and of KwaZulu-Natal. Onderstepoort Journal of Veterinary Research, 62:123-131.

HORAK, I.G., BRAACK, L.E.O., FOURIE, L.J. \& WALKER, JANE B. 2000. Parasites of domestic and wild animals in South Africa. XXXVIII. Ixodid ticks collected from 23 wild carnivore species. Onderstepoort Journal of Veterinary Research, 67 239-250.

HORAK, I.G. \& MATTHEE, SONJA 2003. Parasites of domestic and wild animals in South Africa. XLIII. Ixodid ticks of domestic dogs and cats in the Western Cape Province. Onderstepoort Journal of Veterinary Research, 70:187-195.

JACOBS, P.A.H., FOURIE, L.J., KOK, D.J. \& HORAK, I.G. 2001 Diversity, seasonality and sites of attachment of adult ixodid ticks on dogs in the central region of the Free State Prov ince, South Africa. Onderstepoort Journal of Veterinary Research, 68:281-290.

KEIRANS, J.E., WALKER, JANE B., HORAK, I.G. \& HEYNE, HELOISE 1993. Rhipicephalus exophthalmos sp. nov., a new tick species from southern Africa, and redescription of Rhipicephalus oculatus Neumann, 1901, with which it has hitherto been confused (Acari: Ixodida: Ixodidae). Onderstepoort Journal of Veterinary Research, 60:229-246.
NORVAL, R.A.I. 1975. Studies on the ecology of Amblyomma marmoreum Koch 1844 (Acarina: Ixodidae). Journal of Parasitology, 61:737-742.

NORVAL, R.A.I. 1982. The ticks of Zimbabwe. IV. The genus Hyalomma. Zimbabwe Veterinary Journal, 13:2-10.

NORVAL, R.A.I. 1984. The ticks of Zimbabwe. IX. Haemaphysalis leachi and Haemaphysalis spinulosa. Zimbabwe Veterinary Journal, 15:9-17.

NORVAL, R.A.I. \& COLBORNE, J. 1985. The ticks of Zimbabwe. $X$. The genera Dermacentor and Rhipicentor. Zimbabwe Veterinary Journal, 16:1-4.

PERCHMAN, G.E. 1976. Rhipicentor infestation in the dog: a case report. Rhodesian Veterinary Journal, 7:15-16.

SKINNER, J.D. \& SMITHERS, R.H.N. 1990. The mammals of the southern African subregion. Pretoria: University of Pretoria.

SPICKETT, A.M. \& HEYNE, H. 1988. A survey of Karoo tick paralysis in South Africa. Onderstepoort Journal of Veterinary Research, 55:89-92.

STAMPA, S. 1959. Tick paralysis in the Karoo areas of South Africa. Onderstepoort Journal of Veterinary Research, 28: 169-227 + 1 map.

THEILER, GERTRUD 1949. Zoological Survey of the Union of South Africa: Tick Survey. Part III. Distribution of Rhipicephalus appendiculatus, the brown tick. Onderstepoort Journal of Veterinary Science and Animal Industry, 22:269-284 + 1 map.

THEILER, GERTRUD 1961. A contribution to the knowledge of African Ixodidae. The genus Rhipicentor. Revue de Zoologie et de Botanique Africaines, 66:297-308.

THEILER, GERTRUD 1962. The Ixodoidea parasites of vertebrates in Africa south of the Sahara (Ethiopian region). Project S 9958. Report to the Director of Veterinary Services, Onderstepoort. Mimeographed.

WALKER, JANE B. 1991. A review of the ixodid ticks (Acari: Ixodidae) occurring in southern Africa. Onderstepoort Journal of Veterinary Research, 58:81-105.

WALKER, JANE B., KEIRANS, J.E. \& HORAK, I.G. 2000. The genus Rhipicephalus (Acari, Ixodidae): a guide to the brown ticks of the world. Cambridge: Cambridge Academic Press. 